\title{
Aging histological changes in the cartilages of the cricoarytenoid joint ${ }^{1}$
}

\author{
Rogério Aparecido Dedivitis ${ }^{2}$, Márcio Abrahão ${ }^{3}$, Manoel de Jesus Simões ${ }^{4}$, Osvaldo Alves Mora ${ }^{4}$, Onivaldo Cervantes ${ }^{3}$
}

Dedivitis RA, Abrahão M, Simões MJ, Mora OA, Cervantes O. Aging histological changes in the cartilages of the cricoarytenoid joint. Acta Cir Bras [serial online] 2004 Mar-Apr;19(2). Available from URL: http://www.scielo.br/acb.

\begin{abstract}
Purpose: Analysis of ossification, bone marrow formation, perichondrium thickness, muscle fibers, collagen fibers and elastic fibers quantities of cricoid and arytenoid cartilages. Design: Correlation morphologic study. Methods: Twenty-four cricoarytenoid joints were obtained from Caucasian male fresh cadavers divided into three groups with eight specimens in each: group I - adolescents, from 15 to 20; group II - adults, from 25 to 35; and group III - elderly, from 60 to 75. The specimens were stained with H-E; trichrome; Picrosirius; and elastic stain. Histometry was performed for quantitative analysis. Bonferroni Test, Fisher Test and the Variance Analysis were used. Results: At the microscopic analysis, the group I specimens presented typical hyaline cartilage, thin perichondrium, bulky muscle fibers and were surrounded by collagen fibers. In group II, there were ossification in small well defined central areas of four specimens, with lamellar bone tissue. In two of these cases there were central bone cavity full of fat tissue. The other parameters were similar to group I. In group III, most part of hyaline cartilage was replaced by typical lamellar bone tissue with poorly outlined haversian systems. Hematopoietic tissue was noted in six cases and fat tissue in the other two. Perichondrium was thicker. Small muscle fibers were smaller and surrounded by collagen in great quantity. Elastic fibers were present in small quantity in the outer portion of perichondrium in all the groups. Conclusions: In spite of its lack in adolescence, ossification occurs in cricoid and arytenoid cartilages during adulthood and intensifies with age; bone marrow is formed in ossification tissue with hematopoietic tissue in group III; perichondrium becomes thicker in group III; muscle tissue atrophies in group III and is replaced by collagen fibers; these fibers thicken with age; and elastic fibers is always present in the perichondrium in low quantity.
\end{abstract}

KEY WORDS - Cricoid cartilage. Arytenoid cartilage. Age groups. Cadaver.

\section{Introduction}

Laryngeal complex maturation can lead to structural changes and a typical elderly voice. Voice changes related to the aging process have been attributed to irregularities in vocal fold vibration, glottal incompetence, vocal fold atrophy, and laryngeal tension. Associated with these mechanical factors are the presence of systemic illnesses and the normal agerelated growth and histological changes noted in the laryngeal connective tissues ${ }^{1}$. The effect of the physiologic aging on the structure and function of the cricoarytenoid joints (CAJ) is not well known.
The presence of calcium deposit at roentgenogram ${ }^{2}$ and muscle degenerative changes $^{3}$ are supposed to be indicators of aging of CAJ. Besides the CAJ disfunction in the aged men, change in mass of vocal folds, for example, atrophy and/or edema, is considered to be the greatest factor in their voice changes ${ }^{4}$.

The CAJ is formed by the apposition of the arytenoid and cricoid cartilages' articular facets. The arytenoid facet consists of a small oval concavity on the undersurface of the cartilage's muscular process and body ${ }^{5}$. The cricoid facet, located on the superior aspect of its lamina, is also oval but convex and oriented upward, outward and anteriorly. The CAJ is a real diarthrose with a joint capsule reinforced posteriorly by a ligament and internally lined by a synovial membrane ${ }^{6}$. The cartilage ossification begins after bone growth is completed. The ossification pattern is typically endochondral in the laryngeal cartilages with little perichondrium participation ${ }^{7}$. Ossification begins first in the superior border of the lamina in the cricoid cartilage. The apices, bodies and muscular processes of the arytenoid cartilages shows ossification, but it is not seen in the vocal processes ${ }^{8}$. A true ossification process starts in laryngeal cartilages as early as the twentieth year. Bone formation occurs before in males than in females.

1. Department of Otorhinolaryngology - Head \& Neck Surgery. Department of Histology. Federal University of São Paulo (UNIFESP) - Paulista School of Medicine (EPM)

2. PhD, Post-Graduation Course in .Otorhinolaryngology, Head and Neck Surgery, UNIFESP - EPM. Chairman of Department of Otorhinolaryngology - Head \& Neck Surgery of UNIMES, Santos, São Paulo - Brazil.

3. Professor of Department of Otorhinolaryngology - Head \& Neck Surgery. UNIFESP - EPM.

4. Professor of Department of Histology Discipline, UNIFESP - EPM. 
Laryngeal cartilages that ossify are of the hyaline variety. The transition between elastic and hyaline cartilage portions is gradual, and the border between them is not clearly delineated and the arytenoids come into contact mainly at their elastic cartilage portions at adduction ${ }^{9}$. Fatty and hematopoietic marrow are observed after the thirties in magnetic resonance imaging ${ }^{10}$. On the surface the collagen fibers run parallel to the surface and are vertical in the deep zone ${ }^{11}$. The articular facet is subjected to a variety of forces. While its periphery is stressed by muscle forces, central areas appear to be subjected to the loading of the arytenoid cartilage against the cricoid. The collagen fibers may play an important role in the efficient utilization of synovial fluid and in the redistribution of forces within the articular surface during movement ${ }^{12}$.

The articular surfaces are smooth and glistening without evidence of ossification of fibrillation in the young group. Older CAJ articular surfaces are roughened and exhibit fibrillated and ossified areas. These surface changes diminish the smoothness of arytenoid motion, reducing the extent and degree of vocal fold approximation during phonation, diminishing its quality ${ }^{13}$.

Our objective was comparatively analyze (a) the ossification of cricoid and arytenoid cartilages; (b) bone marrow formation; (c) perichondrium thickness; (d) muscle fibers; (e) collagen fiber; and (f) elastic fiber quantities in adolescents, adults and elderly tissues.

\section{Methods}

Human CAJ removed from twenty-four post-morten examinations were evaluated. They were obtained from Posto MédicoLegal de Santos, of Polícia Civil do Estado de São Paulo. They had died from four to twelve hours before the necropsy. The cadavers were Caucasian and male and they were divided into three groups with eight specimens each: group I or adolescents - from 15 to 20-years-old; group II or adult - from 25 to 35 ; and group III or elderly - from 60 to 75 . The average and the median of age were respectively: group I - 18,1 and 18,5-years-old; group II $-30,1$ and 30; and group III - 70,4 and 70,5. Smoking and drinking histories were not available. No one cadaver had laryngeal cause of death. One CAJ was obtained from each cadaver.
The specimens were preserved in $10 \%$ neutral buffered formalin and were sagittally cut at the level of the median portion of the arytenoid cartilage. Slow decalcification was achieved in 5\% formic acid from three to ten days. The specimens were dehidratated and cut as thick as 5 $\mathrm{mm}$. Slides were stained with hematoxylineosin, Masson trichrome, Picrosirius and Weigert elastic stain. The macroscopic appearance of the specimens was evaluated according to colour and consistency at manual palpation.

Ossification and bone marrow were qualitatively analyzed according to their presence or absence in each specimen. A measurement optic coupled to a light microscope was used for the perichondrium thickness calculation. Four measures far from each other were taken for each specimen being half in each articular surface. As it differentiates striated muscle from collagen fibers, trichrome stain was used for the histometric analysis, which is based on bidimensional stereology principles ${ }^{14,15}$. The Histologist examining the specimens was blinded to further information of the patient prior to histological examination.

The data were presented as averages and standard deviations. The averages were compared according to the Variance Analysis method. A confidence interval of $95 \%$ ( $p<0.05$ ) has been used to express statistical significance. When a group average differed from an other, Bonferroni's method was used to detect them. Fisher's Exact Test was used to verify the difference between the frequencies of the groups, with a significance of $95 \%$.

\section{Results}

The adolescent and adult cartilaginous specimens presented similar morphologies at macroscopic level. They were white nacreous, homogeneous, smooth, shiny, fibrous elastic and surrounded by typical muscle fibers. In the elderly group, the cartilaginous specimens were yellow, heterogeneous, rugous, with no brightness and hard. The muscle tissue was also hard. The central portion of six specimens presented aspect of typical bone marrow (Figure 1).

In group I, the cricoid and arytenoid cartilages exhibited hyaline matrices with chondrocytes which were typically flattened in the articular surface and rounded in the deep portion, either isolated or aggregated. The perichondrium was thin and consisted of chondroblasts, mesenchymal cells and collagen fibers. Muscle fibers inserted into the perichondrium and large and surrounded by some collagen fibers. Elastic fibers were present in the outer part of the perichondrium in small quantities (Figure 2).

In group II, while four cricoid and arytenoid articular specimens were typical hyaline cartilage, the other four showed inner ossification. It occurred in limited areas in the deep part of the cartilages. The bone tissue was lamellar, with lamellae parallel to the cartilage surface. In two cases, the bone cavities were full of adipose tissue. The perichondrium, inserted striated muscle, collagen and elastic fibers had aspect similar to those of the adolescent group (Figure 3).

In group III, most part of the hyaline cartilage is replaced by typical lamellar osseous tissue with the presence of some Havers systems. Typically hyaline cartilage tissue surrounded the bone as a thin layer. In the deep portion of of these specimens there was bone cavity with true hematopoietic tissue in six and adipose tissue in the other two. The cartilage consisted of chondrocytes which were more flattened nea $=r$ the articular surface. The perichondrium was thicker with a high density of collagen fibers. The elastic fibers in this group is also present in small quantity in the outer part of the perichondrium (Figures 4 to 7 ).

Table 1 presents the data achieved according to the different groups. Perichondrium thickness and the quantity of muscle fibers and collagen were comparatively measured.

It was obtained the value $\mathrm{p}<0,001$ for each variable - perichondrium, muscle fibers and collagen. Our analysis demonstrates that the null hypothesis is excluded and there is a different average at a 95\% level for one of the groups. According to the Fisher Exact Test at a level of significance of $95 \%$, all the adolescent specimens present no ossification. In the elderly group each showed positive ossification, indicating an association between ossification and age. The association between the presence of bone marrow and the age groups showed $p<0.05$. The $p$ value is marginally significant between adult and elderly groups at a level of $93 \%$. 


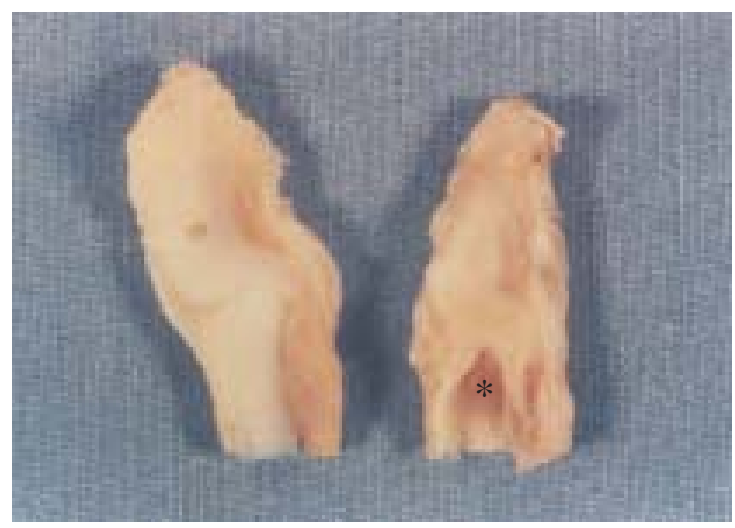

FIGURE 1 - Photography of young and elderly CAJ. The cartilage of the former is white-nacreous while it is yellow and filled by marrow cavity $(*)$ in the elderly (x8).

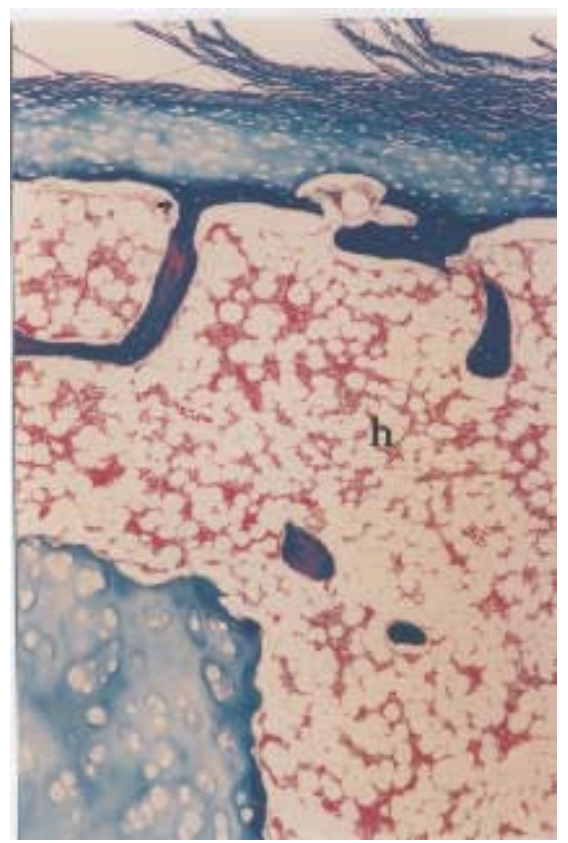

FIGURE 3 - Photomicrography of an adult CAJ with hematopoietic tissue (h) in bone tissue and ossification areas (arrow) in its periphery (trichrome stain, x240).

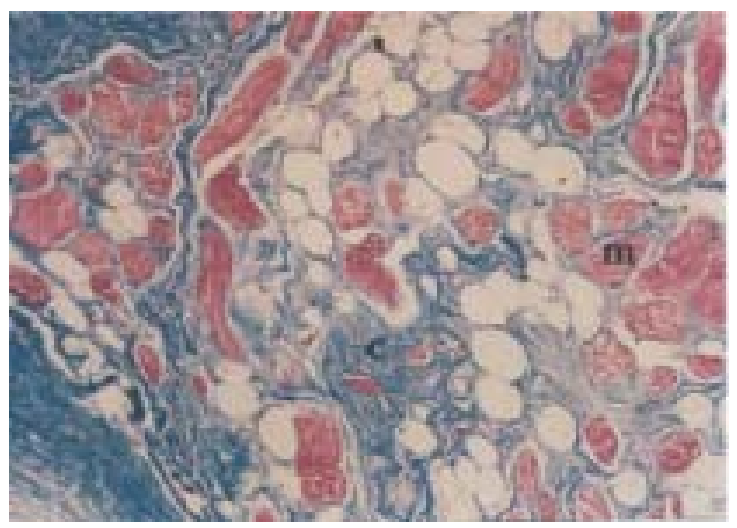

FIGURE 6 - Photomicrography of an elderly CAJ with striated muscle fibers (m) and large clusters of collagen fibers (c) surrounding them (trichrome, x240).

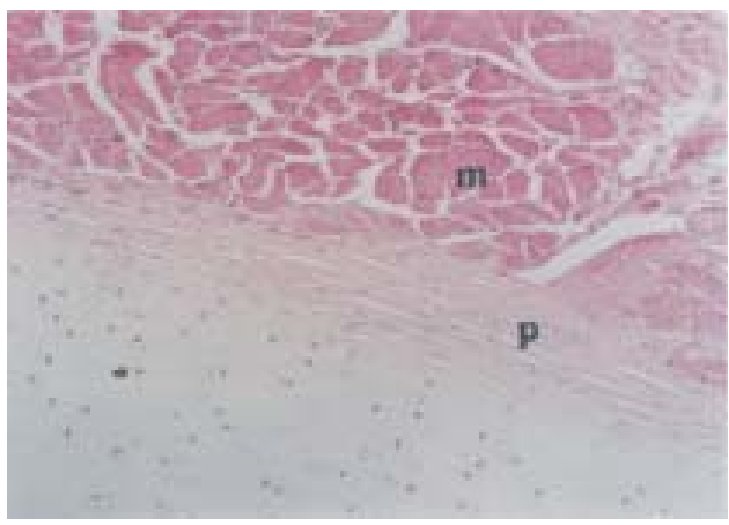

FIGURE 2 - Photomicrography of a young CAJ with a typical cartilaginous matrix with chondrocytes (arrow) and surrounded by the perichondrium (p). Striated muscle fibers (m) are inserted in it (trichrome, $\mathrm{x} 140$ ).

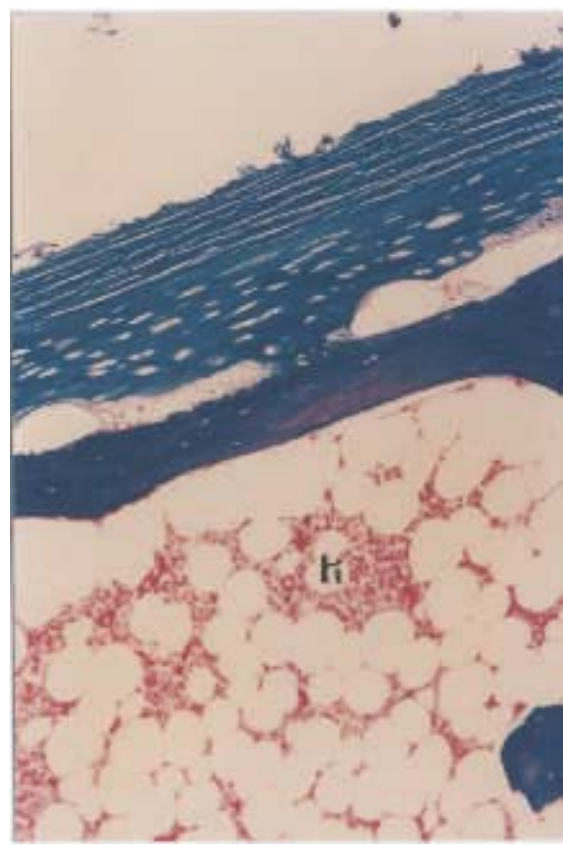

FIGURE 4 - Photomicrography of an elderly CAJ with bone marrow and typical hematopoietic tissue (h) in the cartilage. There is bone tissue around it. (trichrome, 140X).

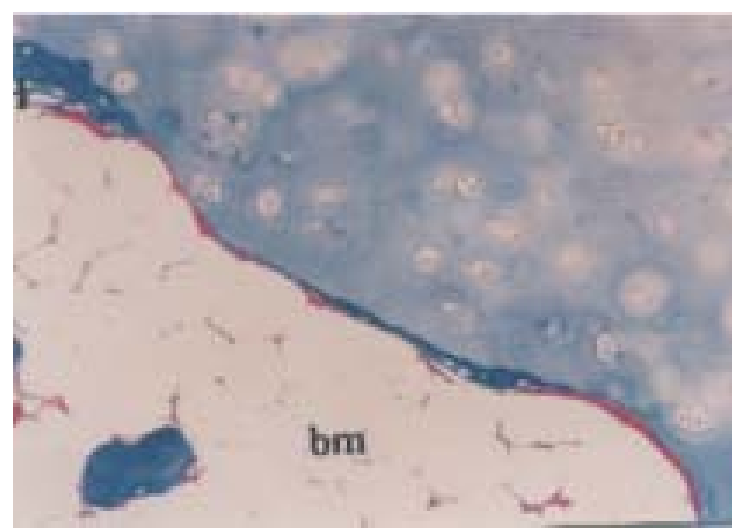

FIGURE 5 - Photomicrography of an elderly CAJ with typical bone marrow $(\mathrm{bm})$ surrounded by lamellar bone tissue and Havers systems (H) (trichrome, x280). 


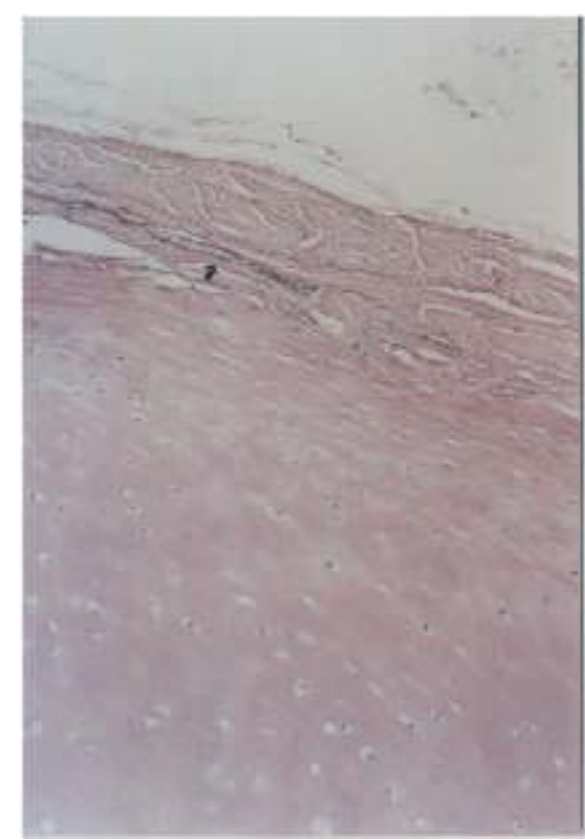

FIGURE 7 - Photomicrography of an elderly CAJ with few elastic fibers (arrow) through perichondrium (Weigert, x140).

\section{Discussion}

Regressive processes in the articular cartilages, such as surrounding muscle fiber degeneration, and progressive ones such as ossification are continuous and occur mainly in the elderly. However, they occur in different ways and intensities between individuals and there are also variations between different organs of the same person ${ }^{16}$.

The erosion and loss of smoothness of the CAJ articular surfaces in the elderly group possibly can affect the movement of the joint and the position of the vocal folds during phonation, leading to vocal changes. Besides the histological changes in elderly, there can also be the influence of systemic pathological processes, for example, rheumatic and bacterial arthritis and other external factors that impact on the voice.

The articular joints develop a degenerative process due to an imbalance between their resistance capacity and the charge they are underwent. It depends on the time, the individual exposure to different charge regimens on the joint. In our series, all the elderly specimens presented these changes. The most significant and consistent change is an increase in the amount of ossification in laryngeal specimens from older individuals particularly in the cricoid cartilage. Cricoid and arytenoid

TABLE 1 - Average and standard deviation data achieved for the groups.

\begin{tabular}{lccc}
\hline Group & Perich. $(\mathbf{m m})$ & Muscle fibers & Collagen \\
\hline - - Adolescents & $0.2712 \pm 0.041$ & $63.125 \pm 3.091$ & $3.625 \pm 1.408$ \\
II - Adults & $0.3025 \pm 0.052$ & $62.250 \pm 4.062$ & $2.500 \pm 1.604$ \\
III - Elderlies & $0.4625 \pm 0.037$ & $25.625 \pm 4.173$ & $62.750 \pm 7.778$ \\
Average \pm S.D. & $0.2712 \pm 0.041$ & $63.125 \pm 3.091$ & $3.625 \pm 1.408$ \\
\hline
\end{tabular}

ossification is present subcortically in younger specimens with involvement of the center of the cartilage in older larynges. No significant changes are noted in dense collagen and elastin deposition ${ }^{1}$. Ossification and calcification should be differentiated, specially because it is generally assumed that any calcium deposit at cervical roentgenograms in normal laryngeal cartilages is due a calcification process ${ }^{2,10}$. While the calcification is secondary to any previous lesion and is more common in elderly, the ossification occurs after the forties and is caused by an involution of the cartilaginous tissue and its replacement by typical lamellar bone with true hematopoietic tissue.

The ossification process begins during adulthood. In the arytenoid, while the apex, body and muscular process present ossification, it never occurs in the vocal process and in its cranial portion, which are composed of elastic cartilage ${ }^{12}$ which is not susceptible to ossification.

The finding of hematopoietic tissue into the ossification areas has been described previously ${ }^{6,11}$. It was present in small quantities even in the adult specimens and more intensively in the elderly. The yellow to brown colour of the aged cartilage can be due to the deposition of hematopoietic substances in the matrix ${ }^{13}$.

Degenerative muscle changes in elderly larynges have been described previously ${ }^{3}$. A progressive reduction in the articular muscle mass was clearly noted in our specimens due to muscle fibers atrophy and to collagen fibers deposition between them. We did not find any significant variation in elastin deposition in the groups. It is the amorphous component of the elastic fibers. Elastin is present is small quantities near the articular surface.

\section{Conclusions}

1) In spite of its absence in adolescence, ossification develops in cricoid and arytenoid cartilages during adulthood, being more intense in elderly group; 2 ) bone marrow is formed in the ossified tissue of CAJ with hematopoietic tissue in group III; 3) the perichondrium becomes thicker in both cartilages in elderly group; 4) muscle inserted in perichondrium atrophies in group III and is replaced by collagen fibers; 5) these fibers thicken with age; and 6) elastic fiber quantity is low independently of age and they are present in the perichondrium.

\section{References}

1. Casiano RR, Ruiz PJ, Goldstein W. Histopathologic changes in the aging human cricoarytenoid joint. Laryngoscope 1994;104:533-8

2. Chamberlain E, Young BR. Ossification (socalled "calcification") of normal laryngeal cartilages mistaken for foreign body. A correlation of roentgen and histologic findings. Am J Roentgenol Rad Ther 1935;33:441-50

3. Bach AC, Lederer FL, Dinolt R. Senile changes in the laryngeal musculature. Arch Otolaryngol 1941;34:47-56.

4. Honjo I, Isshiki N. Laryngoscopic and voice characteristics of aged persons. Arch Otolaryngol 1980;106:149-50.

5. Sellars I, Sellars S. Cricoarytenoid joint structure and function. J Laryngol Otol 1983;97:1027-34

6. Cérat J, Charlin B, Brazeau-Lamontagne L, Mongeau CJ. Assessment of the cricoarytenoid joint: high-resolution CT scan study with histo-anatomical correlation. J Otolaryngol 1988;17:65-7.

7. Chiewitz S. Untersuchungen Über Die Veränderungen Der Menschlichen Kehlkopfknorpel. Arch Anat Entweklngsgesch 1882;303-49.

8. Hately W, Evison G, Samuel E. The pattern of ossification in the laryngeal cartilages: a radiological study. Br J Radiol 1965;38:58591.

9. Sato K, Kurita S, Hirano M, Kiyokawa K. Distribution of elastic cartilage in the arytenoids and its physiologic significance. Ann Otol Rhinol Laryngol 1990;99: 363-8.

10. Sakai F, Gamsu G, Dillon WP, Lynch DA, Gilbert TJ. MR Imaging of the larynx at 1.6 T. J Comp Ass Tomogr 1990; $14: 60-71$. 
11. Bullough P, Goodfellow J. The significance of the fine structure of articular cartilage. J Bone Joint Surg 1968;50B:852-7.

12. Kahane JC, Kahn AR. India ink pinprick experiments on surface organization of cricoarytenoid joints. J Speech Hear Res 1986;29:544-8.
13. Kahn AR, Kahane JC. India ink pinprick assessment of age-related changes in the cricoarytenoid joint (CAJ) articular surfaces. J Speech Hear Res 1986;29:536-43.

14. Underwood EE. Stereology or the quantitative evaluation of microstructure. J Microsc 1968;89:161-90.
15. Weibel ER, Kistler GS, Scherle WF. Practical stereological methods for morphometric cytology. J Cell Biol 1970;30:23-38.

16. Amprino R, Bairati A. Studi sulle trasformazione delle cartilagini Del l'uomo nell'accrescimento e nella senescenza. Z Zellforsch Mikrosk Anat 1933;20:143-205.

Dedivitis RA, Abrahão M, Simões MJ, Mora OA, Cervantes O. Alterações histológicas com a idade nas cartilagens da articulação cricoaritenóidea. Acta Cir Bras [serial online] 2004 Mar-Abr;19(2). Disponível em URL: http://www.scielo.br/acb

RESUMO - Objetivo: Análise da ossificação, formação de medula óssea, espessura do pericôndrio, da quantidade de fibras musculares, de colágeno e eláticas das cartilagens cricóidea e aritenóidea. Desenho: Estudo morfológico comparativo. Métodos: Vinte e quatro articulações crico-aritenóideas foram obtidas de cadáveres frescos caucasianos masculinos, divididos em três grupos com oito espécimes cada: grupo I - adolescentes, de 15 a 20 anos; grupo II adultos, de 25 a 35; e grupo III - idosos, de 60 a 75. Os espécimes foram corados com H.E.; tricrômio; Picrosirius; e coloração para fibras elásticas. Histometria foi realizada para a análise quantitativa. Teste de Bonferroni, Teste Exato de Fisher e a Análise de Variância foram utilizados. Resultados: À análise microscópica, os espécimes do grupo I apresentaram cartilagem hialina típica, pericôndrio fino, fibras musculares espessas e cercadas por colágeno em pequena quantidade. No grupo II, havia ossificação em pequenas áreas centrais bem definidas em quatro espécimes, com tecido ósseo lamelar. Em dois desses casos, havia uma cavidade óssea central preenchida por tecido adiposo. Os demais parâmetros foram similares ao grupo I. No grupo III, a maior parte da cartilagem hialina estava substituída por típico tecido ósseo lamelar com sistemas de Havers. Tecido hematopoiético foi observado em seis casos e tecido adiposo nos outros dois. O pericôndrio estava espesso. As fibras musculares estavam menores e cercadas por colágeno em grande quantidade. Fibras elásticas estavam presentes em pequena quantidade na porção externa do pericôndrio em todos os grupos. Conclusões: Apesar de sua ausência na adolescência, a ossificação occorreu nas cartilagens cricóidea e aritenóidea durante a idade adulta e intensificou-se com a idade; medula óssea é formada no tecido de ossificação com tecido hematopoiético no grupo III; o pericôndrio tornou-se espesso no grupo III; as fibras musculares atrofiaram no grupo III e foram substituídas por fibras de colágeno; estas fibras espessaram-se com a idade; e as fibras elásticas estavam sempre presentes no pericôndrio em pequena quantidade.

DESCRITORES - Cartilagem cricóide. Cartilagem aritenóide. Grupos etários. Cadáver.

Conflict of interest: none

Financial source: $\mathrm{CNPq}$

Correspondence:

Rogério A. Dedivitis

Rua Olinto Rodrigues Dantas, 343/92

11050-220 Santos - SP

Tel/Fax: (13)3221-1514/3223-5550

dedivitis.hns@uol.com.br

Data do recebimento: $26 / 11 / 2003$

Data da revisão: 05/01/2004

Data da aprovação: 19/02/2004 